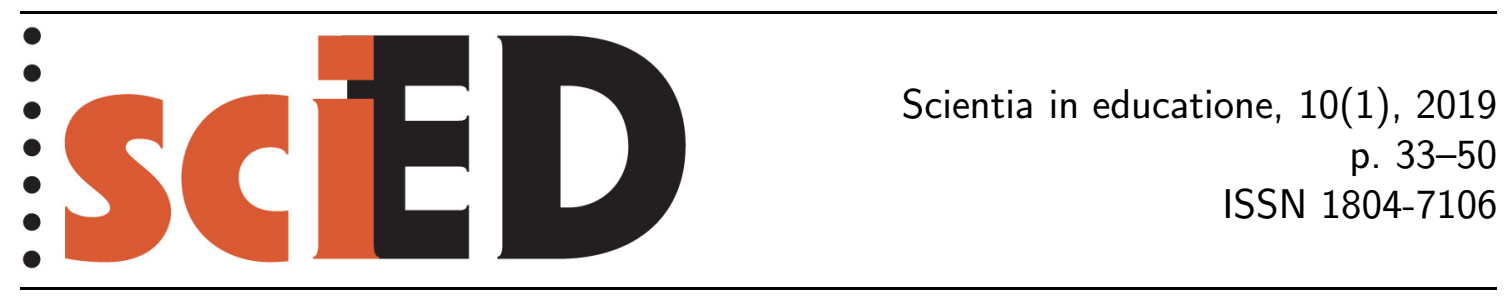

\title{
Vstupní znalosti účastníků geovědních táborů zjištované asociační technikou
}

\author{
Martina Pražáková, Lenka Pavlasová
}

\begin{abstract}
Abstrakt
Zjištování znalostí žáků má svůj nezastupitelný význam ve formálním vzdělávání, v neformálním vzdělávání se s ním ale př́liš často nesetkáváme. Tato studie popisuje výzkum, který se opírá o dvoudimenzionální pojetí kognitivních znalostí žáků a byl realizován slovním asociačním testem. Jeho prostřednictvím odvozujeme aktuální porozumění žáků $(n=143)$ oblasti neživé přírody. Výsledná zjištění určují úroveň vstupních teoretických i praktických znalostí účastníků geovědních táborů v dimenzích znalostí faktuálních, konceptuálních, procedurálních a metakognitivních. Byla prokázána statisticky významně vyšší úroveň teoretických konceptuálních znalostí u starších žáků (více než 12 let) a dívek. Doporučujeme tedy, aby se ve výuce témat o neživé přírodě v neformálním vzdělávání kladl důraz na rozvoj geovědních praktických znalostí žáků, které jsou specifické pro tuto oblast přírodních věd a kde vnímáme jejich deficit. Neformální vzdělávání by se tak u žáků se zájmem o neživou přírodu stalo vhodným doplňkem ke vzdělávání formálnímu.
\end{abstract}

Klíčová slova: znalosti, neformální vzdělávání, geovědy, vědecký tábor, slovní asociační test.

\section{Initial Knowledge of Geoscience Camps' Participants Analysed by the Association Technique}

\begin{abstract}
Knowledge testing is a key part of formal education. However, it is rarely used in nonformal education. This research describes an analysis based on a two-dimensional approach to pupils' cognitive knowledge. It was performed by a word association test which helps the examiners ascertain the pupils' real understanding $(n=143)$ of geoscience. Its outcomes define the level of initial theoretical and practical knowledge of geoscience camp participants' in the following four dimensions of knowledge: factual, conceptual, procedural and metacognitive. It proves that older pupils (older than 12 years) and girls show statistically significantly higher level of theoretical conceptual knowledge. Therefore, our recommendation for teaching the geoscience topics in non-formal education is to emphasize the practical abilities of pupils, which are specific to this area of natural science and whose deficiency we can perceive. For pupils interested in geoscience, non-formal education might become a convenient addition to the formal one.
\end{abstract}

Key words: knowledge, non-formal education, geosciences, science camp, word association test. 
Přírodovědné vzdělávání se dlouhodobě zaměřuje na rozvíjení individuálních znalostí a kompetencí žáků. Jeho cílem je, aby žák v průběhu vzdělávání získal základní přírodovědnou gramotnost. Nedílnou součástí přírodovědného vzdělávání jsou geovědní témata, která jsou obsažena především v učivu předmětů prvouka, přírodověda i přírodopis na základní škole, viz tematický okruh Neživá příroda ve vzdělávací oblasti Člověk a př́roda, RVP ZV (MŠMT, 2016) a v učivu samostatného vzdělávacího oboru Geologie na gymnáziích, RVP G (VÚP, 2007). Obsah učiva v povinném vzdělávání se do značné míry odráží i ve vzdělávání neformálním, které se odehrává např́klad na vědeckých táborech.

Geovědní tábory jsou úzce specializovanou formou vědeckých táborů (Pražáková \& Pavlasová, 2017b). Umožňují prostřednictvím realizace činnostně zaměřených aktivit, zahrnutých do programu, představit žákům učivo o neživé př́ŕrodě (Pražáková \& Pavlasová, 2017a). Z kognitivního hlediska mohou mít vliv na rozvoj úrovně přírodovědných znalostí žáků (Hadjachilleos, Valanides \& Leou, 2004) a pochopení interdisciplinárních souvislostí (Esteves et al., 2013). Při integraci a rozvíjení přírodovědných znalostí žáků by proto geovědní tábory mohly doplňovat vzdělávání, které se odehrává ve formální podobě. Geovědní tábory jsou stále častěji využívaným způsobem neformálního vzdělávání a v současné době zaznamenáváme v Ceské republice jejich rozvoj (Pražáková \& Pavlasová, 2017b). Lze očekávat, že se mohou podílet nejen na prohlubování žákovských zájmů o studium neživé přírody, ale také na utváření jejich oborových geovědních znalostí.

Z tohoto důvodu jsme se zaměřili na zjištování vstupních znalostí žáků různých věkových skupin, abychom mohli určit oblasti a věkové skupiny, kde jsou př́padně znalosti nižší, a doporučit volbu činností na táborech, aby docházelo k optimálnímu doplnění již stávajících znalostí žáků.

\section{TEORETICKÁ VÝCHODISKA}

\subsection{PRAKTICKÉ A TEORETICKÉ ZNALOSTI O NEŽIVÉ PŘírodĚ, JEJICH UTVÁŘENÍ}

V oborově didaktickém pojetí znalosti žáků o neživé přírodě vnímáme jako výsledek procesu poznávání skutečností, jejich vlastností, vztahů k jiným skutečnostem v oblasti geovědní problematiky (přeformulováno podle Janík, 2018: s. 5). Zdrojem znalostí, které jsou u žáki̊ formovány a rozvíjeny v oblasti neživé př́írody, jsou vědní obory v oblasti geověd (vědy o Zemi, geologie). Jedná se např. o obecnou geologii, petrologii, mineralogii a další disciplíny. Informace z těchto oborů jsou klíčovými pro didaktické koncipování obsahu přírodovědného vzdělávání žáků o neživé přírodě.

Znalosti žáků se utváří v rozsahu mezi pamětově i prakticky orientovanými kognitivními operacemi v jejich mysli, viz znalosti v širším pojetí v publikaci Průchy, Walterové a Mareše (2003: s. 312). Jsou tedy pro potřeby terminologie obtížně dělitelné do subjednotek. V této studii znalosti žáků o geovědním obsahu oboru, které jsou utvářené převážně pamětovými procesy, označíme jako geovědní znalosti teoretické (vědomosti). Znalosti žáků, které jsou také utvářeny kognitivními procesy, ale nesou v sobě informaci o procesní složce oboru, zde označíme jako geovědní znalosti praktické. Jedná se např. o znalosti experimentálních technik, znalosti vědeckých konceptů a teorií (Eurydice, 2006 - výstupy přírodovědného vzdělávání).

Pro bližší představu o zde studovaném rozsahu geovědních teoretických a praktických znalostí žáků vycházíme podobně jako Hanus a Marada (2013) z taxono- 
mické tabulky vzdělávacích cílů (revidovaná Bloomova taxonomie) v kognitivní rovině (tab. 1), kterou podle Andersona a Kratwohla ${ }^{1}$ přeložila Hudecová (2004). Zde se teoretická i praktická složka znalostí vymezují mezi všemi definovanými styčnými plochami dimenze znalostí a dimenze kognitivních procesů. Při souběžném rozvíjení praktických i teoretických znalostí o neživé přírodě se u žáků zvyšuje šance, že si geovědní znalosti dlouhodobě uchovají (viz Kali, Orion \& Eylon, 2003; Podroužek, 2011). Utváření obou typů znalostí u žáků je nedílnou složkou konstruktivisticky orientovaného geovědního vzdělávání.

Tab. 1: Teoretické a praktické znalosti žáků ve dvou dimenzionálních rovinách (upraveno podle Hudecová, 2004)

\begin{tabular}{lcccc}
\hline Dimenze znalostí & \multicolumn{4}{c}{ Dimenze kognitivního procesu } \\
& Zapamatovat & Porozumět & Aplikovat Analyzovat Hodnotit & Tvořit \\
\hline Faktuální & & & \\
\hline Konceptuální & & & \\
\hline Procedurální & & & \\
\hline Metakognitivní
\end{tabular}

Jestliže žák ovládá vybrané teoretické i praktické geovědní znalosti, je to dílčí krok, který přibliží žáky k úspěšné realizaci konkrétní oborově-specifické činnosti. Metaforicky řečeno se spíše ale bude jednat o recept, na jehož konci je konkrétní představa v mysli žáka o této aktivitě. I přesto nemusí žák být schopen výslednou činnost úspěšně realizovat, bude-li postrádat další pro ni potřebné geovědní teoretické a praktické znalosti nebo dovednosti. Se znalostmi žáků proto úzce souvisí integrální pojem dovednosti, které Čudová (2015: s. 14) na základě detailní rešerše literatury vymezuje jako vědomosti a operace s nimi.

Při osvojování si znalostí o neživé př́rodě se utváří kognitivní struktury v mysli žáka neboli mentální/vnitřní obsahové reprezentace (Janko, 2012). Tyto struktury jsou zcela individualizovanou záležitostí. Kognitivní struktury v mysli žáků, které se týkají rozsahu znalostí o neživé přírodě, se konstruují během procesu kognitivní transformace obsahu geověd (Janík, 2018: s. 2). V př́ípadě teoretických znalostí o neživé přírodě nás například zajímá, jaké kognitivní struktury a jakým sledem dějů si žáci ve své mysli formují, pokud si zapamatují nějaký konkrétní geovědní pojem, koncept, proces či metakognitivní informaci, která je součástí obsahového rámce oboru. Dále také, jaké struktury se zformují v případě, kdy se s geovědními informacemi u žáků uskuteční další kognitivní procesy popsané v tab. 1, tedy porozumění, aplikování apod. U praktických geovědních znalostí nás zajímá, jaké kognitivní struktury jsou utvořeny $\mathrm{v}$ myslích žáků $\mathrm{v}$ př́padě, že si osvojí znalosti o analýze procesů, tvoření procesů a dalších kategoriích v uvedeném rozmezí praktických geovědních znalostí.

\subsection{ZJIŠŤOVÁNí ZNALOSTÍ ŽÁKU POMOCÍ ASOCIAČNÍCH TECHNIK}

Pro výzkumné diagnostikování teoretických a praktických znalostí žáků se užívá rozmanitých technik ${ }^{2}$ (přehledně nejčastěji užívané techniky ukazuje Janík, 2005: s. 55)

\footnotetext{
${ }^{1}$ Anderson, L. W. \& Kratwohl, D. R., et al. (2000). A taxonomy for learning, teaching, and assessing: A revision of Bloom's taxonomy of educational objectives. Pearson Education.

${ }^{2}$ Termín výzkumná technika označuje konkrétní, přesně stanovený nástroj ke shromažd’ování, analýze či vyhodnocování dat výzkumu. Jedná se o specifickou část daného postupu, metody (Průcha, 1995: s. 35).
} 
v neformálním, ale také ve formálním vzdělávání, kde se mohou způsoby a metody prověřování znalostí žáků lišit. Mezi nimi se setkáváme s tzv. asociačními technikami (Průcha, 1995), které byly již dříve rozvíjeny v oblasti výzkumu znalostí ve formálním vzdělávání u nás (Novák \& Kalous, 1989). Jejich výhodou je, že umožňují přistupovat ke znalostem žáků bez dřive vytvořených schémat a předsudků, eliminují vyjadřovací dovednosti a poskytují diferencovanější spektrum informací (Novák \& Kalous, 1989). Současně použití asociačních technik pro účel objasnění znalostí může vést $\mathrm{k}$ výsledným zjištěním o kognitivních strukturách a intra-strukturálních vztazích v myslích žáků (např. Malmos, Jász \& Revák, 2017). Nevýhodou asociačních technik je jejich omezená možnost při interpretaci dat (Novák \& Kalous, 1989; Janík, 2005). Výzkumné metody, které používají asociačních technik při zjištování znalostí, mohou mít různou podobu, v písemné formě se jedná např́klad o slovní asociační test (Assaraf \& Orion, 2005; Malmos, Jász \& Revák, 2017), pojmové mapy (Assaraf \& Orion, 2005; Prokša, 2007), brainwriting (Reichel, 2009: s. 144), metodu verbálních výpovědí (Gavora, 1998).

Asociační technika se ve výzkumu znalostí zaměřuje na zjištování slovních asociací žáků ve vztahu ke stimulujícím/podnětovým pojmům. Slovní asociace žáků jsou vnímány jako individuální kognitivní zpracování zkušeností žáků, které vypovídají o vědomí zpracovatele asociace (Novák \& Kalous, 1989). Uvedená technika se zdá být použitelnou pro zjištování asociací žáků v souvislosti se znalostmi žáků ve všech dimenzích až do dimenze porozumění z pohledu kognitivních procesů, viz tab. 2 .

Tab. 2: Úrovně kognitivních procesů v dimenzi porozumění. Podle L. W. Andersona \& D. R. Kratwohla, et al. (2000) přeložila Hudecová (2004). Tučně je vyznačena úroveň, ve které předpokládáme souvislosti znalostí s asociacemi

Kategorie a kognitivní proces

Porozumět - konstruování významu na základě ústního, písemného nebo grafického sdělení

Interpretace

\section{Doložení příkladem}

Klasifikování

Sumarizování

Usuzování

Porovnávání

Vysvětlování

Podle výše uvedeného je předpokládáno, že se při vyjádření vlastních asociací žáci pokoušejí dokládat př́íkladem specifická fakta, koncepty, procesy, metakognitivní informace, které se váží ke stimulujícímu pojmu. V některých vyjádřeních se setkáváme až s pokusy o klasifikaci vlastních asociací žáky (např. žáci popisují geologické útvary od nejstaršího známého po nejmladší, jmenují planety sluneční soustavy podle lokalizace vzhledem ke Slunci). Pro zjištování pokročilejších úrovní a dimenzí kognitivních procesů je nicméně vhodné zvážit použití alternativních technik a postupů (viz např. Assaraf \& Orion, 2005).

\section{Cíle ŠETření, VÝZKUMNÉ OTÁZKY A HYPOTÉZY}

Ve výzkumu vycházíme z výše popsaných souvislostí mezi vlastními asociacemi a teoretickými i praktickými znalostmi žáků. Cúlem výzkumu bylo zjistit, jaké jsou četnosti asociací, a tím pádem i stav znalostí účastníků/žáků geovědních táborů v ob- 
lasti neživé přírody. Při formulování výzkumného cíle jsme mimo jiné zohlednili výsledky pilotního šetření, kdy se potvrdilo, že se na vybraném paleontologickém táboře žáci učí společně v různorodé skupině znalostem geovědních disciplín (Pražáková \& Pavlasová, 2016: s. 85-86). Bylo zkoumáno, jak souvisí četnosti asociací o neživé přírodě $\mathrm{s}$ věkem a lišícím se pohlavím žáků. Pro výzkum tedy byly zvoleny věkové kategorie žáků mladších ( $<12$ let) a žáků starších $(\geq 12$ let). Mladší žáci přibližně věkem odpovídali žákům v primární úrovni vzdělávání (ISCED 1), starší žáci žákům v nižší a vyšší sekundární úrovni vzdělávání, ISCED 2 a 3 (UIS, 2011).

Výzkumné otázky byly stanoveny následovně:

$\left(\mathrm{VO}_{1}\right)$ : Které faktory mají vliv na četnosti dosažených asociací souvisejících s teoretickými znalostmi o neživé přírodě u mladších a starších účastníků geovědních táborů?

$\left(\mathrm{VO}_{2}\right)$ : Jaké jsou rozdíly v četnostech asociací souvisejících s teoretickými znalostmi o neživé přírodě u chlapců a dívek na geovědních táborech?

$\left(\mathrm{VO}_{3}\right)$ : Které faktory mají vliv na četnosti zmiňovaných asociací vztahujících se k praktickým znalostem o neživé přírodě u mladších a starších účastníků geovědních táborů?

$\left(\mathrm{VO}_{4}\right)$ : Jak se liší četnosti asociací souvisejících s praktickými znalostmi o neživé př́rodě u chlapců a dívek, kteří se účastní geovědních táborů?

Na základě uvedených výzkumných otázek byly formulovány hypotézy, které vychází z níže uvedených předpokladů:

$\left(\mathbf{H}_{1}\right)$ : Mladší žáci dosahují vyšších hodnot četností u asociací, které souvisí s teoretickými znalostmi o neživé přrírodě než žáci starší. Vycházeli jsme z tvrzení, že mladší žáci mají obecně větší zájem o prŕrodovědné disciplíny (např. Papáček et al., 2015; Vácha, 2017). Vyšší projevený zájem žáků může být argumentem pro dosahování vyšší úrovně asociací souvisejících s teoretickými znalostmi o neživé př́rodě (Hemmer et al., 2007).

$\left(\mathbf{H}_{2}\right)$ : Chlapci dosahují vyšších hodnot četností u asociací v souvislosti s teoretickými znalostmi o neživé přírodě než dívky během geovědních táborů. Předpokládáme, v souladu s Fančovičovou a Kubiatkem (2015), že chlapci se více zajímají o otázky týkající se geověd než dívky, a proto mohou dosahovat vyšších četností u asociací v souvislosti s teoretickými znalostmi.

$\left(\mathbf{H}_{3}\right)$ : Starší účastníci geovědních táborů disponují vyšší četností u asociací, které souvisejí s praktickou znalostí než jejich mladší vrstevníci. Vycházeli jsme z toho, že u starších účastníků nově příchozí informace kooperují s již utvořeným celkově obsáhlejším znalostním základem, který byl vytvořen na základě předchozích zkušeností (Janík, 2018), a proto starší žáci mají i vyšší úroveň aktuálně dosažených asociací souvisejících s praktickými znalostmi.

$\left(\mathbf{H}_{4}\right)$ : Chlapci dosahují vyšší četnosti asociací vážících se k praktickým znalostem než dívky během geovědních táborů. Ukazuje se, že účastníci dobrovolných zájmových aktivit obvykle preferují praktické činnosti k dosahování znalostí (Janštová, Jáč \& Dvořáková, 2015). Protože chlapci jsou častěji účastníky geovědních táborů, předpokládá se jejich větší afinita $\mathrm{k}$ prakticky orientovanému učení. 


\section{MetodikA}

Při výzkumu jsme spolupracovali s pěti neformálními organizacemi z Brna, Nové Paky a Prahy. Výzkumné šetření bylo provedeno v období července - srpna 2017 na jimi pořádaných turnusech geovědních táborů (bliže viz Pražáková \& Pavlasová, 2017a: s. 55).

\subsection{RESPONDENTI}

Výzkumný vzorek tvořili účastníci/žáci geovědních táborů v celkovém počtu $n=143$ (101 chlapců, 42 dívek). Respondenty charakterizuje zájem o neživou přírodu, což dokládá jejich dobrovolná účast na geovědním táboře. Jednoho táborového turnusu se účastnilo přibližně 14 respondentů. Základní údaje o respondentech, které se vztahovaly k námi zvoleným proměnným, jako je jejich věk a pohlaví, popisuje tab. 3.

Tab. 3: Rozložení respondentů podle jejich věku a pohlaví

\begin{tabular}{l|l|r|r|r}
\hline \multicolumn{2}{c|}{ Respondenti } & \multicolumn{2}{|c|}{ Pohlaví } & \multirow{2}{*}{\begin{tabular}{c} 
Celkem \\
\multicolumn{2}{c|}{}
\end{tabular}} \\
\cline { 3 - 4 } & Chlapci & Dívky & (věková kategorie) \\
\hline \multirow{3}{*}{ Věk } & mladší žáci (méně než 12 let) & 72 & 26 & 98 \\
\cline { 2 - 4 } & starší žáci (12 let a více) & 26 & 16 & 42 \\
\cline { 2 - 4 } & neuvedeno & 3 & 0 & 3 \\
\hline \multicolumn{2}{l|}{ Celkem (pohlaví) } & 101 & 42 & 143 \\
\hline
\end{tabular}

Respondenti byli ve věku 6-18 let, tři respondenti svůj věk neuvedli. Jedná se tedy o heterogenní skupinu s ohledem na jejich věk, a tím i dosažené vzdělání.

\subsection{SBĚR DAT, METODY}

Sběr dat se konal vždy v průběhu první poloviny každého táborového turnusu, nejčastěji první nebo druhý den konání tábora. Byl prováděn převážně výzkumníkem nebo lektory tábora, kteří byli pro tento účel proškoleni.

Výzkumnou metodou byl písemný slovní asociační test (Novák \& Kalous, 1989), obsahující tyto části: pokyny k vyplnění, identifikační tabulku a část určenou k vypsání asociací. Tato metoda byla zvolena s ohledem na heterogenitu respondenti̊ (viz kap. 3.1), kdy pro analýzu vstupních znalostí nebylo možné použít jednotný didaktický test určený účastníkům. Zjištovali jsme, jaké slovní asociace si žáci vytváří ve spojení se stimulujícím pojmem „neživá příroda“. Ve studii nebyl zjištóován vztah mezi stimulujícími pojmy (viz koeficient př́buznosti - Malmos, Jász \& Révak, 2017), všechny asociace měly vazbu k jedinému stimulujícího pojmu (podobně jako Assaraf \& Orion, 2005). Stimulující pojem jsme vybrali tak, aby jej znali všichni respondenti a postihoval co nejširší oblast obsahu geověd, se kterou se setkávají během formálního vzdělávání. Byl použit takový stimulující pojem, který je dostatečně ukotven v českých kutikulárních dokumentech pro žáky primární a nižší sekundární úrovně vzdělávání (MŠMT, 2016 - RVP ZV). Stimulující pojem se vztahoval k učivu geověd, které je vyučováno nejčastěji v 5. a 9. ročníku povinného školního vzdělávání. Pro odpověd’ respondentů byl stanoven maximální počet 40 asociací (položek), neomezených slovním druhem. Žáci nebyli limitováni při sdělování asociací časem, vzhledem k rozdílné pokročilosti v projevu ve skupině respondentů. 
Pracovní verze výzkumného nástroje byla připomínkována odborníky (odborný geolog, dva didaktikové přírodních věd, dva učitelé z praxe). Konstruktová validita byla určena tím, že v pracovní verzi výzkumného nástroje byly provedeny úpravy reflektující konkrétní připomínky odborníků a poté došlo k finalizaci výzkumného nástroje. Reliabilita byla spočtena pomocí Cronbachova alfa, které dosáhlo hodnoty 0,855 . Slovní asociační test byl distribuován v tištěné formě, vyplněn účastníky prezenčně a po vyplnění ihned odevzdáván. Návratnost proto činila $100 \%$.

\subsection{ANALÝZA DAT}

Při zpracování dat nejprve došlo k eliminování asociací nerelevantních (nečitelná odpověd', opakující se asociace u shodného respondenta, řada po sobě jdoucích totožných asociací více respondentů v celé odpovědi, apod.). Zjištěné relevantní asociace jsou definovány jako součet všech pojmů zmíněných respondenty. Tyto asociace byly přepsány do textového editoru, jazykově opraveny (např. gramatická správnost, základní jmenné a slovesné tvary - jednotné číslo, infinitiv). Níže je příklad tří přepsaných a přeformulovaných záznamů, jak s nimi bylo dále pracováno:

ID 1: voda, slunce [Slunce], oheň, kameny [kámen], mraki [mrak], žula, srdce, citrín, železo, kov

ID 2: kámen, minerál, šutr, peř́í, hornina, zobák, kost, zub, dráp, voda, vzduch, oheň, slunce [Slunce], spalované dřevo [dřevo], hlína, oblak, led, žula

ID 3: kalcit, diamant, kámen, zlato, stříbro, křištál, křemen, kianid [kyanit], dřevo, skála, kov, hliník, ocel, nerez, důl, lom, vrtat, dinamit [dynamit], vrták, tunel

Dále v odpovědích respondentů byl objasněn stav unikátních asociací, které definujeme jako počet pojmů, které byly započítány $1 \times$ (unikátně) navzdory tomu, že byly uvedeny více respondenty. Unikátní asociace byly přiřazeny do kategorií, které odpovídaly dimenzím znalostí z výše uvedené taxonomické tabulky (tab. 1). Zjištěné unikátní asociace byly dále tříděny do dvou skupin, na asociace s vazbou $\mathrm{k}$ teoretickým nebo praktickým geovědním znalostem. Asociace související s teoretickými znalostmi byly roztříděny $\mathrm{v}$ dílčích kategoriích tímto způsobem [v závorce jsou uvedené př́klady]:

1. Asociace faktuálních znalostí: rod či druh zkameněliny [Ortoceras], druh/název nerostu [křemen] a jeho odrůdy [citrín], druhy/názvy hornin [žula], názvy sopek [Etna], pohoří [Krkonoše], moří [Středozemní moře], planet [Jupiter], půdních typů [černozem].

2. Asociace konceptuálních znalostí: označení skupin neživých přírodnin [minerály] včetně dílčích subtypů [sedimenty], časem ohraničené úseky naší minulosti [prvohory], sféry Země [litosféra], chemické prvky a sloučeniny (+ vlastnosti) [pentahydrát síranu měd’natého], geomorfologické jednotky [nížina].

3. Asociace procedurálních znalostí: přírodní fyzikálně-chemické procesy [světlo], endogenní [desková tektonika] i exogenní [eroze] jevy.

4. Asociace metakognitivních znalostí: geovědní podobory jako informační zdroj [petrologie], vazba ke školní výuce [písemka], zdroje informací o oborovém obsahu [noviny].

Pro skupinu asociací v souvislosti s praktickými znalostmi pak byly asociace rovněž tříděny: 
1. Asociace faktuálních znalostí: názvy nástrojů [kladivo] a technických pomůcek [vzorek] př̀i práci odborníků.

2. Asociace konceptuálních znalostí: vnitřní umístění práce odborníků [laboratoř] i venkovní [lokalita], místa sloužící veřejnosti k neformálnímu poznání neživé př́rody [muzeum], výrobek nerostného původu (+ př́íklad, vlastnost) [mramorový sloup].

3. Asociace procedurálních znalostí: informace o dílčích krocích odborné práce [preparace].

4. Asociace metakognitivních znalostí: údaje spojené se zaměstnáním odborníků [vědec], zkušenosti z táborů [jméno lektora].

V celém souboru relevantních i unikátních asociací byly vytříděny asociace, které je možné zahrnout do skupiny bliže nespecifikovaných asociací respondentů o neživé přírodě. Jedná se nejčastěji o asociace, u nichž z terminologického hlediska nelze určit jejich přesný význam (napřr. asociace kámen může a nemusí označovat minerál, horninu či slučovat oba termíny dohromady, asociace dřevo může a nemusí označovat zkamenělé dřevo). Nebo se jedná o asociace, které pravděpodobně s neživou přírodou nesouvisí (např. banán, jahoda). S těmito asociacemi nebylo pracováno v další analýze relevantních a unikátních asociací.

V tabulkovém editoru byly vypočteny kontingenční tabulky s absolutními $(n)$ a relativními $\left(n_{R}\right)$ četnostmi u relevantních a unikátních asociací respondentů. Zjištěné relativní četnosti obou typů asociací byly graficky znázorněny. Bližší popis unikátních asociací nám umožnil ověřit charakter dat v celém zjištěném souboru relevantních asociací. To umožnilo další analýzu dat ve skupině relevantních asociací, která se vztahuje k definovaným výzkumným otázkám a hypotézám. Následně byly ve statistickém programu vypočítány průměrné hodnoty $(M)$ a směrodatné odchylky $(s)$ výskytů relevantních asociací, které byly zjištovány v souvislosti s vymezenými dimenzemi geovědních znalostí respondentů. V nich byla testována normalita počtu asociací pomocí Shapiro-Wilkova testu. Bylo zjištěno, že ani v jedné dimenzi není normální rozložení ( $p$ hodnoty $<0,05$ ), proto k porovnání rozdílů mezi věkovými kategoriemi a pohlavím byl použit neparametrický Mann-Whitneyho U test. Všechny testy byly hodnoceny v hladině $5 \%$ významnosti.

\section{VÝSLEDKY}

Výsledky výzkumu ukazují celkem $n=2078$ čitelných asociací ve výběrové skupině 143 respondentů (101 chlapců, 42 dívek). Jeden respondent uvedl průměrně 15 asociací. Nerelevantních asociací bylo $n=289(13,5 \%)$, Tyto asociace nebyly pro další analýzu dat použity. Asociací relevantních bylo $n=1789$ (86,5\%). Výzkumná skupina respondentů uvedla celkem $n=452$ unikátních asociací o neživé přírodě (viz kap 3.3).

Mezi relevantními a unikátními asociacemi respondentů byly $\mathrm{v}$ dalším kroku identifikovány respondenty blíže nespecifikované asociace. U relevantních asociací se jednalo o $n=181$ asociací (tj. $10 \%$ ), u unikátních asociací se jednalo o $n=37$ asociací (8\%). Z celého výčtu je v tab. 4 ukázáno patnáct blíže nespecifikovaných asociací, které uváděli respondenti v souvislosti s neživou přírodou. Zde uvedená asociace kámen je mezi respondenty nejčastěji zmiňovanou asociací (byla uvedena celkem 94 respondenty, tj. 65,7\% respondentů). 
Tab. 4: Př́iklady blíže nespecifikovaných asociací, které uváděli respondenti ke stimulujícímu pojmu „neživá příroda“ (řazeno abecedně)

\begin{tabular}{lclcll}
\hline \multirow{2}{*}{ název } & $n_{R}$ & název & $n_{R}$ & název & $n_{R}$ \\
\hline banán & $0,7 \%$ & jahoda & $0,7 \%$ & kopřiva & $0,7 \%$ \\
\hline borůvka & $0,7 \%$ & kaluž & $65,7 \%$ & kost & $3,5 \%$ \\
\hline dráp & $0,7 \%$ & kámen & $1,4 \%$ & kostra & $1,4 \%$ \\
\hline dřevo & $0,7 \%$ & keř & $3,5 \%$ & lebka & $1,4 \%$ \\
\hline hrouda & $8,4 \%$ & kopec & $0,7 \%$ & les & $2,1 \%$ \\
\hline
\end{tabular}

Po eliminování skupiny blíže nespecifikovaných asociací došlo k sumarizaci celkem $n=1617$ relevantních asociací a celkem $n=415$ unikátních asociací ve výzkumném souboru respondentů. Zastoupení relevantních asociací v souvislosti s oblastí teoretických i praktických znalostí o neživé přírodě ve výpovědích respondentů je vidět v grafu 1. Respondenti uváděli relevantní asociace v kategorii teoretických znalostí výrazně četněji $(n=1505 ; 92,8 \%)$ než asociace o znalostech praktických ( $n=112,7,2 \%$ ). Relevantní asociace z kategorií faktuálních a konceptuálních v četnostech celkem čítají výraznější skupiny $(n=1419 ;$ tj. $93 \%)$ než relevantní asociace $\mathrm{v}$ souvislosti s kategoriemi procedurálních a metakognitivních znalostí (celkem $n=120 ; \mathrm{tj} .7 \%)$.

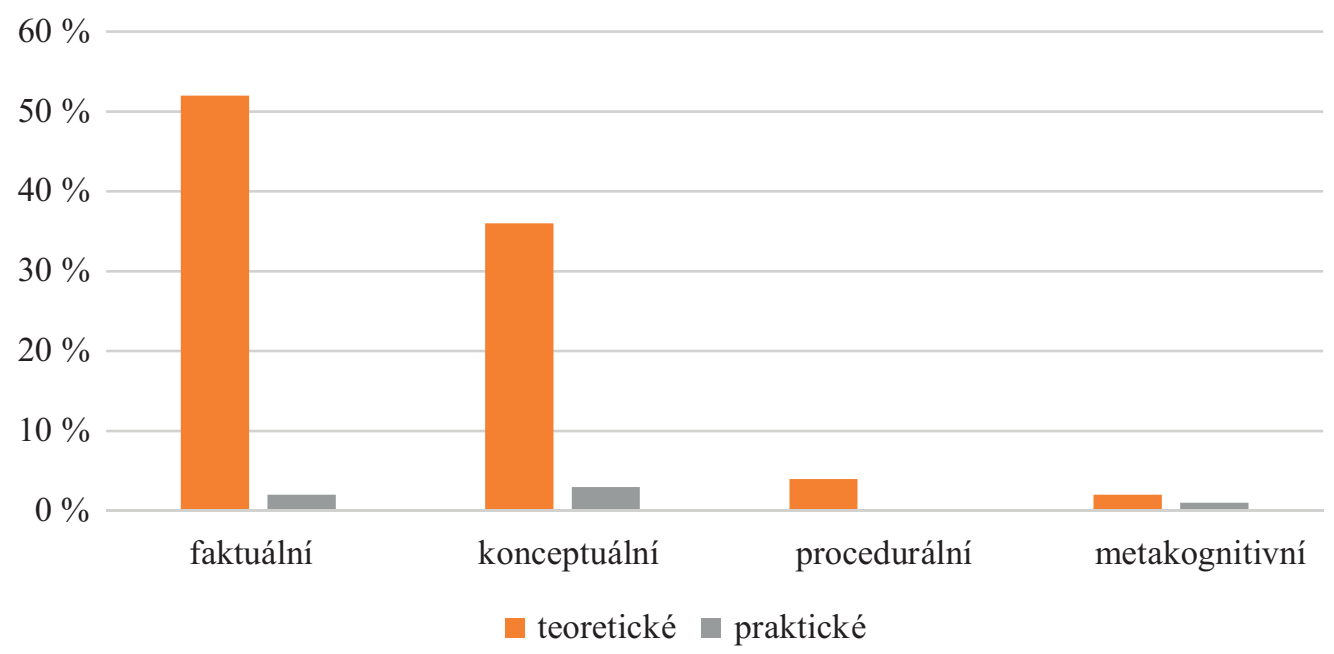

Graf 1: Relevantní asociace uváděné respondenty v souvislosti s teoretickými a praktickými znalostmi

Celkové zastoupení unikátních asociací v souvislosti s kategoriemi teoretických a praktických znalostí shrnuje následující graf 2 . Jak je vidět, unikátní asociace respondentů měly častěji vazbu $\mathrm{k}$ výše uvedeným kategoriím teoretických znalostí $(n=354 ;$ tj. $85 \%)$ než ke kategoriím praktických znalostí $(n=61 ;$ tj. $15 \%)$. Celkově nejvíce unikátních asociací ve výpovědích respondentů bylo identifikováno v kategorii faktuálních a konceptuálních znalostí (celkem $n=373$, tj. $90 \%$ ), nejméně unikátních asociací bylo zjištěno ve skupině procedurálních a metakognitivních znalostí (celkem $n=42 ; \mathrm{tj} .10 \%)$.

Nejčastěji zastoupené unikátní asociace o neživé přírodě v odpovědích celého souboru respondentů $(n=143)$ jsou: voda (zastoupení 44,8 \%), vzduch $(27,9 \%$ ), křemen (25,9\%), minerál $(24,5 \%)$ a zkamenělina (24,5\%). Prvních patnáct unikátních asociací s relativně nejvyšší frekvencí mezi respondenty ukazuje tab. 5 . 


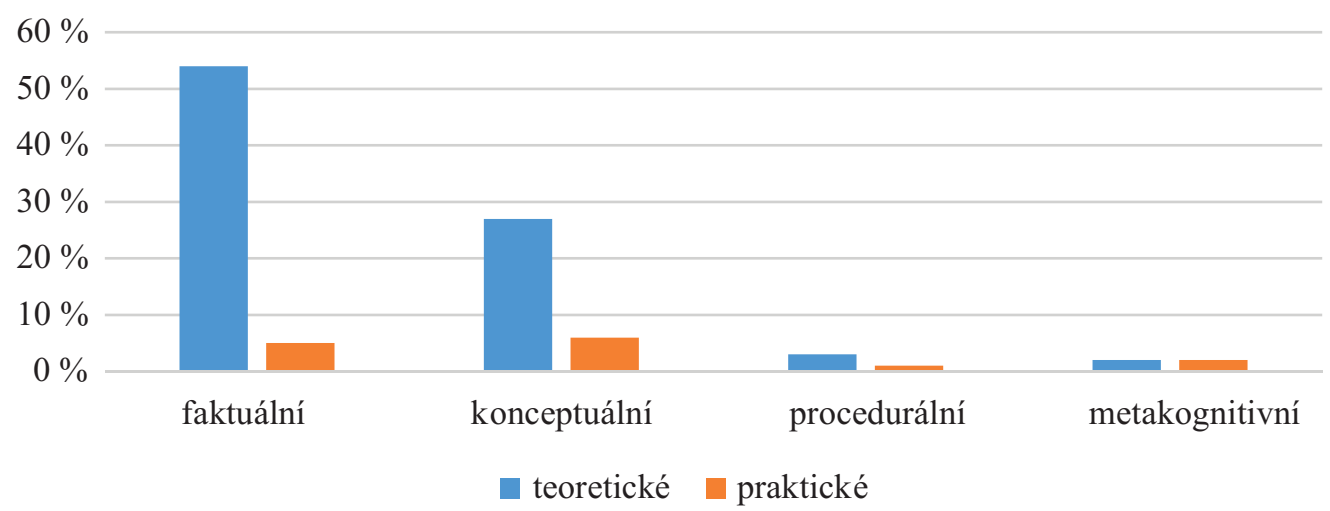

Graf 2: Unikátní asociace uváděné respondenty v souvislosti s teoretickými a praktickými znalostmi

Tab. 5: Nejčastěji se vyskytující unikátní asociace o neživé přírodě u respondentů

\begin{tabular}{lcclcclcc}
\hline \multirow{2}{*}{ název } & $n$ & $n_{R}$ & název & $n$ & $n_{R}$ & název & $n$ & $n_{R}$ \\
\hline voda & 64 & $44,8 \%$ & hornina & 33 & $23,1 \%$ & zlato & 29 & $20,2 \%$ \\
\hline vzduch & 40 & $27,9 \%$ & diamant & 30 & $20,9 \%$ & ametyst & 26 & $18,2 \%$ \\
\hline ǩ́emen & 37 & $25,9 \%$ & hlína & 30 & $20,9 \%$ & skála & 25 & $17,5 \%$ \\
\hline minerál & 35 & $24,5 \%$ & láva & 30 & $20,9 \%$ & sopka & 25 & $17,5 \%$ \\
\hline zkamenělina & 35 & $24,5 \%$ & písek & 30 & $20,9 \%$ & žula & 23 & $16,1 \%$ \\
\hline
\end{tabular}

\subsection{ASOCIACE MLADŠÍCH A STARŠÍCH ŽÁKŮ V OBLASTI NEŽIVÉ PŘ́́RODY}

Celkově byly hodnoty pro různé věkové skupiny žáků spočteny ve skupině $n=140$ respondentů (98 mladších, 42 starších), tj. u 97,9 \% žáků účastnících se výzkumu. Stav relevantních asociací, které uváděli mladší a starší žáci v souvislosti s teoretickými znalostmi o neživé př́rodě, ukazuje tab. 6 .

Tab. 6: Hodnoty zjištěné u starších a mladších žáků v oblasti teoretických znalostí, průměr $(M)$, směrodatná odchylka $(s)$, $p$-hodnota byla vypočtena pomocí Man-Whitney U testu na hladině významnosti $5 \%$. Symbolem * je označena statisticky významná hodnota

\begin{tabular}{lcccccccc}
\hline Teoretické znalosti & \multicolumn{2}{c}{ Faktuální } & \multicolumn{2}{c}{ Konceptuální } & \multicolumn{2}{c}{ Procedurální } & \multicolumn{2}{c}{ Metakognitivní } \\
\cline { 2 - 9 } & $M$ & $s$ & $M$ & $s$ & $M$ & $s$ & $M$ & $s$ \\
\hline mladš́ žáci & 5,602 & 7,062 & 3,316 & 3,014 & 0,306 & 0,633 & 0,051 & 0,221 \\
starši žáci & 6,476 & 6,975 & 5,857 & 4,981 & 0,667 & 1,588 & 0,690 & 1,259 \\
\hline$p$-hodnota & \multicolumn{2}{c}{0,188} & $0,020^{*}$ & 0,157 & 0,186 \\
\hline
\end{tabular}

Mladší žáci celkově uvedli průměrně méně asociací ve všech dimenzích teoretických znalostí o neživé přírodě než žáci starší. Statisticky významná hodnota byla zjištěna pouze u konceptuálních znalostí žáků $(p=0,020)$, kdy starší žáci uvádí prokazatelně více asociací ve zmíněné dimenzi znalostí. Nejvíce asociací průměrně uváděli mladší i starší žáci v oblasti faktuálních znalostí, následně znalostí konceptuálních. Průměrné zastoupení asociací v kategorích procedurálních a metakognitivních znalostí bylo zanedbatelné. 
V hodnotách, které uváděli mladší a starší žáci v souvislosti s praktickými znalostmi o neživé př́rodě, nebyly nalezeny žádné statisticky významné parametry. U mladších a starších žáků souhrnně je nejvýraznější zastoupení asociací v oblasti faktuálních znalostí respondentů (mladší žáci $M=0,122$, starší žáci $M=0,667$, $p=0,369)$. Nejnižší jsou souhrnné hodnoty zjištěné $\mathrm{u}$ asociací v souvislosti s procedurálními znalostmi respondentů (mladší žáci $M=0,031$, starší žáci $M=0,119$, $p=0,369)$. Je možné zde ovšem sledovat trend, kdy se mezi uvedenými dimenzemi průměrně více (vyšší hodnoty $M$ ) objevují asociace ve vztahu k praktickým geovědním znalostem u starších žáků než u žáků mladších.

\subsection{ASOCIACE CHLAPCŮ A DÍVEK V OBLASTI NEŽIVÉ Př́íRODY}

Výsledky zjištěné pro různé pohlaví žáků byly ve výzkumu zjištěny u 143 respondentů (101 chlapců, 42 dívek), tj. u 100 \% respondentů účastnících se výzkumu. Stav relevantních asociací vztahujících se k teoretickým znalostem, které uvedli respondenti obou pohlaví, je vidět v tab. 7 .

Tab. 7: Hodnoty zjištěné u chlapců a dívek v oblasti teoretických znalostí, průměr $(M)$, směrodatná odchylka $(s)$, $p$-hodnota byla vypočtena pomocí Man-Whitney U testu na hladině významnosti $5 \%$. Symbolem * je označena statisticky významná hodnota

\begin{tabular}{lcccccccc}
\hline Teoretické znalosti & \multicolumn{2}{c}{ Faktuální } & \multicolumn{3}{c}{ Konceptuální } & \multicolumn{2}{c}{ Procedurální } & \multicolumn{2}{c}{ Metakognitivní } \\
\cline { 2 - 9 } & $M$ & $s$ & $M$ & $s$ & $M$ & $s$ & $M$ & $s$ \\
\hline chlapci & 5,812 & 7,355 & 3,327 & 3,536 & 0,317 & 1,029 & 0,158 & 0,579 \\
dívky & 5,905 & 5,983 & 5,738 & 4,073 & 0,619 & 0,962 & 0,452 & 1,064 \\
\hline$p$-hodnota & \multicolumn{2}{c}{0,444} & $<0,005^{*}$ & 0,746 & 0,853 \\
\hline
\end{tabular}

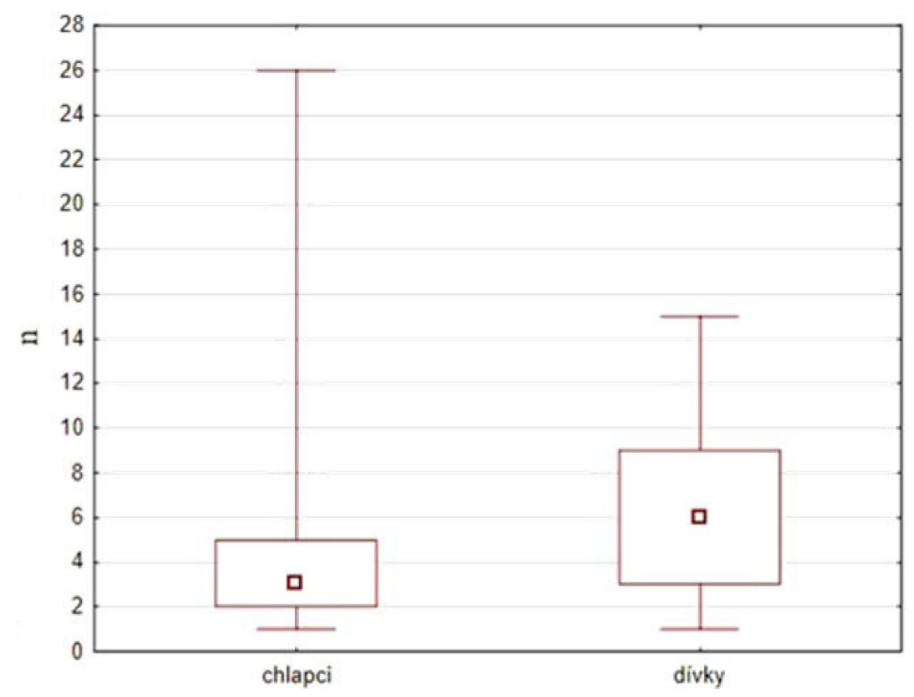

Graf 3: Krabicový graf pro teoretické konceptuální znalosti (chlapci a dívky)

Dívky celkově uvedly průměrně více asociací ve vztahu ke všem dimenzím teoretických znalostí o neživé přrírodě než chlapci. Statisticky významný údaj byl zjištěn opět v hodnotě vztahující se ke konceptuálním znalostem žáků $(p<0,005)$, $\mathrm{k}$ nimž se také vztahují údaje v grafu 3. Zobrazené výsledky ukazují proměnlivé hodnoty mezi identifikovanými četnostmi asociací u chlapců a dívek. Každý chlapec uvádí 
nejčastěji dvě až pět asociací v souvislosti s uvedenou dimenzí, dívka tři až devět. Dívky uvádí celkově maximálně 15 či méně asociací, chlapci na rozdíl od dívek dosahují vyšších absolutních četností, maximálně až 26 asociací souvisejících s dimenzí konceptuálních znalostí.

Hodnoty o praktických znalostech chlapců a dívek jsou, podobně jako hodnoty zjištované pro různé věkové kategorie, zanedbatelné. $\mathrm{V}$ souhrnném zjištění dívky dosahují průměrně vyšších hodnot ve všech dimenzích, nicméně statisticky nevýznamně. Hodnoty se však nachází v rozmezí hodnot $M=0,040$ až $M=0,357$, od nižších hodnot asociací v souvislosti s procedurálními znalostmi u chlapců, ve prospěch směrem $\mathrm{k}$ asociacím souvisejícím s konceptuálními znalostmi u dívek.

\subsection{SHRNUTÍ VÝSLEDKŮ}

V odpovědích žáků jsme v celém souboru asociací $(n=2078)$ eliminovali zjištěné nerelevantní a blíže nespecifikované asociace. Vymezili jsme asociace relevantní ( $n=1617)$ a dále také asociace unikátní $(n=415)$, abychom dokázali citlivěji zachytit nejen asociace teoretického typu, ale také takové, které mohou souviset s praktickými znalostmi žáků. Při porovnání četností relevantních a unikátních asociací bylo nicméně potvrzeno, že zjištěné relevantní asociace zmiňované žáky mají charakter související především s jejich teoretickými znalostmi (relevantní teoretické a. se zastoupením $93 \%$, unikátní a. = $85 \%$ ). Obdobně se shodně projevilo rozložení četností u obou typů asociací převážně ve vztahu k dimenzi faktuálních a konceptuálních znalostí žáků.

Další analýza dat se vztahovala k námi sledovaným proměnným ve skupině relevantních asociací respondentů. V oblasti teoretických znalostí byly, navzdory stanovené hypotéze (H1, viz kap. 2) a výchozím předpokladům, zjištěny vyšší průměrné četnosti asociací u dvanáctiletých a starších účastníků geovědních táborů. Statisticky významně pak v zastoupení průměrných četností asociací, které souvisejí s konceptuálními znalostmi žáků. Dívky uváděly průměrně vyšší četnosti asociací ve všech dimenzích teoretických znalostí, taktéž s hodnotami statisticky významnými u dimenze znalostí konceptuálních. Jak je vidět, ani zde nebyla potvrzena námi stanovená hypotéza (H2) o vyšší intervenci chlapců z pohledu zjištování jejich znalostí. Ačkoli všechny průměrné hodnoty zjištěné v souvislosti s praktickými znalostmi žáků nejsou statisticky významné, v souladu s hypotézou (H3) je sledovatelný shodný trend. Průměrně více četně zde popisují asociace praktického typu starší žáci. U hypotézy (H4) shodně s výsledky k hypotéze v oblasti teoretických znalostí (H2) také průměrně četněji uvádí asociace dívky.

\section{DisKUSE}

Znalosti naší společnosti o neživé přírodě jsou podle mezinárodní organizace $\mathrm{AGI}^{3}$ nedostatečné (např. AGI, 2012: s. 19) a vztah lidí je k neživé složce př́írody viditelně negativní (Van Loon, 2007). V České republice, podobně jako v zahraničí, dochází spolu s tím k pozvolnému oslabení pozice témat o neživé přrírodě mezi ostatními přírodovědnými oblastmi ve školním (Sláviková, Igaz \& Adam, 2012), ale i neformálním vzdělávání. Přrirodovědné znalosti se dlouhodobě snižují i v dobrovolném, volnočasovém vzdělávání žáků (Cídlová, 2017). V blízké budoucnosti by se eliminování témat

\footnotetext{
${ }^{3}$ The American Geosciences Institute, dostupné z http://www.americangeosciences.org.
} 
o neživé přírodě ve vzdělávání mohlo projevit na dalším poklesu přírodovědných znalostí u mladých lidí. To by ovšem bylo v rozporu s evropským konsenzem k rozvíjení prŕrodovědné gramotnosti u našich žáků, který reflektuje výsledky mezinárodních srovnávacích šetření.

Tato studie přináší výsledky o četnostech asociací žáků v oblasti neživé přírody, které lze dávat do souvislostí s jejich geovědními znalostmi. K měření četností došlo v neformálním vzdělávání na geovědních táborech, nebot se jedná o př́iklad typu neformální edukace, která je pozitivně vnímaná odborníky v oborové didaktice (např. Papáček et al., 2015). Snahou bylo zaznamenat horní hranici asociací a s nimi souvisejících vstupních znalostí o neživé přírodě, které dosahují žáci daného pohlaví a věku. Proto se ve výzkumu jednalo o skupinu účastníků geovědních táborů, tedy o žáky motivované a preferující praktický přístup k vlastnímu učení (Janštová, Jáč \& Dvořáková, 2015; Pražáková \& Pavlasová, 2016). Výzkumná zjištění nicméně i po zavedení dvou typů sledovaných asociací potvrzují převažující četnosti asociací, které souvisejí s teoretickými znalostmi před četnostmi asociací ve vztahu k praktickým znalostem i u zkoumaných respondentů (kap. 4 - viz graf 1, graf 2). To je v souladu s výsledky mezinárodních výzkumů, které ukázaly vyšší úroveň teoretických (znalosti obsahu, prokazování znalostí) a nižší úroveň praktických znalostí žáků (Blažek \& Př́ihodová, 2016; Tomášek, Basl \& Janoušková, 2016) v přírodovědném vzdělávání v oblasti neživé př́rody.

Rozdílné úrovně ve znalostech jsou možným důsledkem stále uplatňovaných tradičních metod výuky v př́rodovědném vzdělávání, které mohou používat v oblasti neživé přírody jak učitelé (napřr. Michovská, 2008), tak lektoři geovědních táborů (Pražáková \& Pavlasová, 2017a). Také se může jednat o dosavadní vliv školního vzdělávání na žáky, kdy si žáci snáze vybavují znalosti získané během výuky př́rodovědných předmětů. Zde může jít o zvyklost, kdy žáci ve výzkumu operují s teoretickými znalostmi, protože jsou obvykle za účelem diagnostiky znalostí podrobováni testování, které je zaměřeno na teorii. Testování praktické složky se pro ně pak stává neočekávatelné a ani jim praktické znalosti nemusí připadat v dané situaci důležitými. Ve výzkumu se tak potvrdila Janíkova (2005) zkušenost s použitím asociačních technik, která je předurčuje k získávání především teoretických (deklarativních) znalostí jak u učitelů, tak i u žáků. Z toho důvodu je dle Janíkova (2005) doporučení plánováno zjištěné výsledky srovnat a doplnit s výsledky, které byly získány pomocí alternativních postupů.

Ve vztahu k teoretickým i praktickým znalostem o neživé přírodě dosahují ve výzkumu nižších hodnot v četnostech asociací mladší žáci. Dle výsledků (kap. 4.1) je vidět, že prvotní předpoklad (H1, viz kap. 1) zohledňující vztah mezi úrovní znalostí a úrovní zájmu o neživou př́írodu v daném věku žáků nebyl potvrzen. Výsledky nicméně pozitivně korelují s dosavadně nižší mírou zkušeností mladších žáků (předpoklady pro H3, kap. 1), a tím pádem i s jejich celkově méně obsáhlými znalostmi v oboru (Janík, 2018). Tento jev empiricky dokládá tvrzení Váchy (2017), ze kterého vyplývá, že si mladší žáci osvojují menší rozsah zejména teoretických poznatků právě během školního vzdělávání.

Na základě výzkumných zjištění proto doporučujeme, aby došlo zejména u mladších žáků k přednostnímu podněcování praktických znalostí o neživé přírodě ve všech uvedených dimenzích znalostí i dimenzích kognitivních procesů (tab. 1) jak v neformálním, tak ve školním přírodovědném vzdělávání. Zejména tím, že budou úměrně věku rozvíjeny schopnosti žáků, které jsou pro geovědy jedinečné (Almquist et al., 2011). Žáci by měli výsledně disponovat prostorově-vizualizačními schopnostmi, uvědomovat si absolutní geologický čas, být schopni aktualistického a systémového myš- 
lení a dokázat interpretovat životní prostředí v minulosti ve srovnání s nynějším, dokázat vědecky zdůvodnit své poznání.

K rozvoji geovědních schopností, a tedy i praktických znalostí, by mohly přispět činnostně zaměřené aktivity, které akcelerují principy badatelství a konají se v podnětném, variabilním prostředí (Esteves, 2015; Papáček et al., 2015: s. 236). Například takové aktivity, kdy žáci získají vlastní zkušenost s experimentováním v laboratoři, s modelováním a simulacemi pomocí digitálních technologií, zkušenost s terénními strategiemi a technikami používanými během bádání v prř́rodě (King, 2008; Almquist et al., 2011). Je nezbytné učitelům i lektorům připravit odpovídající podmínky, jako je rozšíření nabídky kurzů o neživé přrírodě v přípravném vzdělávání, propracované kurikulum (např. King, 2015) a metodická podpora výuky, podpora dalšího vzdělávání učitelů v oblasti geověd, sítování učitelů a jiná neformální setkávání (např. Turanová \& Ružek, 2015), vstřícný přístup z pohledu managementu a kolegiální podpory konkrétní školy apod. Aby dokázali činnostní aktivity plánovat a realizovat za účelem komplexního rozvíjení zaměřeného nejen na faktuální a konceptuální dimenze znalostí žáků.

Použití asociační techniky nám umožnilo díky jejímu kvalitativně-kvantitativnímu charakteru blíže identifikovat hodnoty s vazbou ke konkrétním dimenzím znalostí. Zjištěné statisticky významné hodnoty u konceptuálních teoretických znalostí žáků jsou ve výzkumu esenciálním zjištěním. Žákovské porozumění konceptuálním znalostem v kontextu daného oboru je vnímáno jako kritické místo v geovědním, zejména tradičně orientovaném vzdělávání (Mentlík, Slavík \& Coufalová, 2018). Utvoření konceptuálních znalostí o neživé přírodě je tedy stěžejní z důvodu, aby nově nabyté oborově specifické informace byly pro žáky více srozumitelné (s. 13, tamtéž).

Ve výzkumu účastníků geovědních táborů vidíme paralelu s Esteves (2015), která pro rozvíjení konceptuálních znalostí nabádá vzdělavatele k realizaci terénních činností. Jak bylo zjištěno v dřrivějším výzkumu, zejména terénní činnosti jsou marginálně obsaženy v náplni většiny zkoumaných turnusů geovědních táborů (Pražáková \& Pavlasová, 2017a). Geovědní tábory lze proto považovat vzhledem ke skladbě organizovaných aktivit za formu př́rodovědného vzdělávání, která podněcuje žáky k dalšímu rozvíjení teoretických konceptuálních znalostí v oblasti neživé přírody. Dle výsledků tohoto výzkumu by geovědní tábory mohly srozumitelně zprostředkovat učivo o neživé př́rodě žákům, kteří se podle studie White Wolf Consulting (2009) o studium přrirodních věd zajímají spíše minoritně (dívky, přibližně věkem v nižší a vyšší sekundární úrovni vzdělávání).

Jak je vidět z rešerše literatury předcházející výzkumu, asociační technika v oborově-didaktickém a pedagogickém výzkumu u nás není př́liš často používaná ani rozvinutá (srov. s ostatními technikami např. Gavora, 2000). Někteří autoři doposud asociační techniku označují za techniku projektivní (srov. Fančovičová \& Kubiatko, 2015). Janík (2005: s. 59) upozorňuje, že se asociační technika od technik projektivních odlišuje právě v chybějícím aspektu projekce. Nejasnosti v metodické terminologii mohou být př́činou, proč způsob používání asociačních technik není ve výzkumných pedagogických metodách doposud ustálený.

Náš výzkum ukázal, že je vhodné asociační techniku použít pro zjištování vstupních znalostí žáků. Její výhodou je při sběru dat jednoduché a pro respondenta jednoznačné zadání. Umožňuje práci s rozdílnými skupinami respondentů, které se účastní obsahově obdobně koncipovaného neformálního vzdělávání. Při analýze dat je výhodou techniky možnost je očistit v několika úrovních (nerelevantní asociace, blíže nespecifikované asociace) pro zajištění validních výsledků. Avšak v obou výše 
uvedených bodech zároveň vidíme omezení. Nutnou podmínkou výzkumu je, aby byl výzkum zaměřený na žáky zajímající se o zkoumanou oblast, jejichž verbální schopnosti díky těmto předpokladům mohou být na porovnatelné úrovni s věkově staršími kategoriemi žáků. V neposlední řadě je kategoriální analýza dat a práce s nimi obtížná z pohledu času i zkušeností, které jsou kladeny na výzkumníky a mohou práci s uvedenou technikou komplikovat.

\section{ZÁVĚR}

Na geovědních táborech bylo pro výzkum vstupních znalostí v heterogenní skupině účastníků využito asociační techniky. Metodou slovního asociačního testu došlo ke zjištování četností žákovských asociací o neživé přírodě. Tím byly určeny dosažené teoretické a praktické znalosti ve všech znalostních dimenzích, které odpovídají dimenzi kognitivního procesu porozumění v úrovni doložení př́́kladem.

Ve zjištěném souboru všech asociací relevantních i unikátních byly zjištěny převažující četnosti asociací v souvislosti s teoretickými znalostmi žáků při vstupu do geovědního tábora, tedy před zamýšlenou intervencí mající tyto znalosti ovlivnit. Statisticky významné byly četnosti asociací, které souvisejí s dimenzí konceptuálních teoretických znalostí u dívek a starších žáků (12 let a více).

Doporučujeme tedy, aby se ve výuce témat o neživé přírodě v neformálním vzdělávání již u žáků mladšího věku kladl důraz na rozvoj jejich geovědních praktických znalostí, které jsou specifickými pro tuto oblast př́rodních věd, a kde spatřujeme deficit. Toho lze mimo jiné docílit systematickou podporou lektorů, kteří budou schopni účelně využívat ve vzdělávání činnostně a motivačně zaměřené aktivity a efektivní metody výuky respektující učební styly žáků. Geovědní tábory tak mohou hrát významnou roli v př́rodovědném vzdělávání u těchto žáků při doplňování kritických míst přírodovědného kurikula, které se soustředí na neživou přírodu. Jejich funkce spočívající v doplňování formálního vzdělávání může být poté opodstatněná.

Provedený výzkum nám současně poskytuje zprostředkované informace i o cílech a průběhu formálního vzdělávání, protože právě odtud si žáci přinášejí nižší úroveň praktických znalostí. Můžeme z něho usuzovat na stále přetrvávající důraz na teoretické znalosti, na absenci induktivních postupů při výuce a na nedostatečné propojování poznatků s praxí. Zjištěné výsledky jsou proto důležité nejen pro didaktickou přípravu lektorů neformálního vzdělávání, ale také pro př́pravu učitelů geologických témat na základních i středních školách.

\section{PodĚKOVÁní}

Výzkum byl podpořen programem Progres Q17 Př́prava učitele a učitelská profese $v$ kontextu vědy a výzkumu. Naše poděkování patří zejména organizacím, všem lektorům a žákům, kteří se do výzkumu zapojili. Děkujeme také Ing. Anetě Mazouchové, Ph.D., za metodické konzultace ohledně statistického zpracování dat.

\section{LITERATURA}

AGI, American Geoscience Institute. (2012). Critical needs for the twenty-first century, the role of the geosciences. Dostupné $\mathrm{z}$ https://www.americangeosciences.org/sites/default/files/CriticalNeeds2012.pdf 
Almquist, H., et al. (2011). An integrated field-based approach to building teachers' geoscience skills. Journal of Geoscience Education, 59, 31-40. DOI: 10.5408/1.3543926

Anderson, L. W. \& Kratwohl, D. R., et al. (2000). A taxonomy for learning, teaching, and assessing: A revision of Bloom's taxonomy of educational objectives. Pearson Education.

Assaraf, B. \& Orion, N. (2005). Development of system thinking skills in the context of Earth system education. Journal of Research in Science Teaching, 42(5), 518-560.

Blažek, R. \& Př́hodová, S. (2016). Mezinárodní šetření PISA 2015. Praha: ČṠI.

Cídlová, H. (2017). Klesají znalosti a dovednosti žáků i v jejich zájmové činnosti? In.

J. Válek \& P. Marinič (Eds.), 11. mezinárodní vědecká konference - Didaktická konference (22-27). Brno: MU.

Cuudová, R. (2015). Biologické dovednosti žáků [Disertační práce]. Praha: UK.

Dostupné z https://is.cuni.cz/webapps/zzp/detail/104879/

Esteves, H., et al. (2013). Geological fieldwork: A study carried out with Portuguese secondary school students. Journal of Geoscience Education, 61, 318-325. DOI: $10.5408 / 12-394.1$

Esteves, H. (2015). A field-based approach to teach geoscience: A study with secondary students. Procedia - Social and Behavioral Sciences, 191, 63-67. DOI: 10.1016/j.sbspro.2015.04.323

Eurydice. (2006). Science teaching in schools in Europe. Policies and research. Brussel: EC.

Fančovičová, J. \& Kubiatko, M. (2015). Záujem žiakov nižšieho sekundárneho vzdelávania o biologické vedy. Scientia in educatione, 6(1), 2-13.

Gavora, P. (1998). Metóda verbálnych výpovedí v edukačnmom výskume. In Š. Śvec, et al., Metodológia vied o výchove (122-124). Bratislava: IRIS.

Gavora, P. (2000). Úvod do pedagogického výzkumu. Brno: Paido.

Hadjachilleos, S., Valanides, N. \& Leou, M. (2004). Construction of knowledge in non-formal settings. Science Education International, 15(2), 125-137.

Hanus, M. \& Marada, M. (2013). Mapové dovednosti v českých a zahraničních kurikulárních dokumentech: srovnávací studie. Geografie, 118(2), 158-178.

Hemmer, I., et al. (2007). Students' interest in geoscience topics, contexts and methods. Geographie Und Ihre Didaktik, 35(4), 185-197.

Hudecová, D. (2004). Revize Bloomovy taxonomie edukačních cílů. Pedagogika, 54, $274-283$.

Janík, T. (2005). Znalost jako klíčová kategorie učitelského vzdělávání. Brno: Paido.

Janík, T. (2018). Od obsahu vzdělávání k žákově znalosti: Kritická místa na cestě do školy a ze školy. Arnica, 8(1), 1-8.

Janko, T. (2012). Reprezentace obsahu: psychologická východiska a didaktické souvislosti. Pedagogická orientace, 22(1), 23-40. DOI: 10.5817/PedOr2012-1-23

Janštová, V., Jáč, M. \& Dvořáková, R. M. (2015). Faktory motivující žáky středních škol $\mathrm{k}$ zájmu o obor biologie a účasti v předmětových soutěžích $\mathrm{s}$ biologickou tematikou.

E-pedagogium, 2015(1), 56-71.

Kali, Y., Orion, N. \& Eylon, B. (2003). Effect of knowledge integration activities on students' perception of the Earth's crust as a cyclic system. Journal of Research in Science Teaching, 40(6), 545-565. DOI 10.1002/tea.10096 
King, C. (2008). Geoscience education: an overview. Studies in Science Education, 44(2), 187-222. DOI: $10.1080 / 03057260802264289$

King, C. (2015). The need for an international geoscience school syllabus: Its development and publication. Science Education International, 26(4), 420-438.

Malmos, E., Jász, E. \& Revák, I. M. (2017). Using a word asssociation method to assess knowledge structure of renewable energy sources at primary level. Journal of Science Education, 18(2), 109-113.

Mentlík, P., Slavík, J. \& Coufalová, J. (2018). Kritická místa kurikula, organizační a klíčové koncepty - konceptuální vymezení a př́iklady z výuky geověd. Arnica, 2018(1), 9-18.

Michovská, L. (2008). Výuka geologie na základních a středních školách v České republice - průzkum názorů odborné a laické veřejnosti [Diplomová práce]. Praha: UK. Dostupné z https://is.cuni.cz/

MŠMT. (2016). Rámcový vzdělávací program pro základní vzdělávání. Praha: NÚV. Dostupné z http://www.msmt.cz

Novák, Z. \& Kalous, J. (1989). Test volných slovních asociací jako test školních znalostí. Pedagogika, 4, 431-435.

Papáček, M., et al. (2015). Didaktika biologie: didaktika v rekonstrukci. In I. Stuchlíková \& T. Janík, et al. (Eds.), Oborové didaktiky: vývoj - stav - perspektivy (225-257). Brno: MU.

Podroužek, L. (2011). Komparativní analýza vývoje učiva o horninách, nerostech a půdě v naší primární škole. Arnica, 2011(2), 39-48.

Pražáková, M. \& Pavlasová, L. (2016). Suburban paleontological camp - content and evaluation. In D. Stárková \& M. Rusek (Eds.), Project-based education in science education XIV (81-89). Praha: PedF UK.

Pražáková, M. \& Pavlasová, L. (2017a). What do children do at summer camps? The analysis of geoscience camps' programmes. In M. Rusek \& K. Vojiřr (Eds.), Project-based education in science education: empirical texts XV (53-61). Praha: PedF UK.

Pražáková, M. \& Pavlasová, L. (2017b). Non-formal children and youth education focused on geoscience content. Pedagogická orientace, 27(4), 599-619. DOI: 10.5817/PedOr2017-4-599

Prokša, M. (2007). Pojmové mapy ako výskumný a diagnostický prostriedok v chemickom vzdelávaní. In M. Kuhnová \& J. Miklovičová (Eds.), Inovačné trendy $v$ prírodovednom vzdelávani (98-101). Trnava: TRUNI.

Průcha, J. (1995). Pedagogický výzkum, uvedení do teorie a praxe. Praha: Karolinum.

Průcha, J., Walterová, E. \& Mareš, J. (2003). Pedagogický slovnik, 4., aktualizované vydání. Praha: Portál.

Reichel, J. (2009). Kapitoly metodologie sociálních výzkumů. Praha: Grada.

Sláviková, V., Igaz, C. \& Adam, M. (2012). Postoje žiakov 8. ročníka ZS̆ k predmetu Biológia 8. Biológia, ekológia, chémia, 16(2), 2-4.

Tomášek, V., Basl, J. \& Janoušková, S. (2016). Mezinárodni šetření TIMSS 2015. Praha: ČS̆I.

Turanová, L. \& Ružek, I. (2015). Didaktika geológie na Slovensku - história, súčasný stav a perspektívy. Scientia in educatione, 6(1), 123-132. 
UIS, UNESCO Institute for Statistics. (2011). The International standard classification of education. Dostupné z

http://uis.unesco.org/sites/default/files/documents/international-standard-classificationof-education-isced-2011-en.pdf

Van Loon, A. J. (2007). Geological education of the future. Earth-Science Reviews, 86, 247-254. DOI: 10.1016/j.earscirev.2007.08.005

Vácha, Z. (2017). Žákovská oblíbenost přírodovědy, přírodopisu a biologie. In R. Dytrtová, et al. (Eds.), Výzkum v př́pravě učitelů př́rodovědných, zemědělských a př́buzných oborů (113-137). Praha: Institut vzdělávání a poradenství ČZU.

VÚP, Výzkumný ústav pedagogický. (2007). Rámcový vzdělávací program pro gymnázia. Dostupné z http://www.nuv.cz/file/159

White Wolf Consulting. (2009). Důvody nezájmu žáků o přírodovědné a technické obory. Dostupné z http://vzdelavani.unas.cz/duvody_nezajmu_obory.pdf

MARTINA PRAŽÁKOVÁ, prazakmartina@gmail.com

LENKA PAVlasová, lenka.pavlasova@pedf.cuni.cz

Univerzita Karlova, Pedagogická fakulta

Katedra biologie a environmentálních studií

Magdalény Rettigové 4, 11639 Praha 1, Česká republika 